\title{
Genetic Variation of Stomatal Traits in Four Tomato Hybrids and their Parental Lines
}

\author{
Chennem Kiran Kumar Reddy ${ }^{1 *}$, Sudheer Kumar Jain ${ }^{1}$, M.B. Arun Kumar ${ }^{1}$, \\ S. Gopala Krishnan ${ }^{2}$, Awani Kumar Singh ${ }^{3}$ and Zakir Hussain ${ }^{4}$
}

\author{
${ }^{1}$ Division of Seed Science \& Technology, ${ }^{2}$ Division of Genetics, ${ }^{3}$ Centre for Protected \\ Cultivation and Technology, ${ }^{4}$ Division of Vegetable Science, Indian Agricultural Research \\ Institute, New Delhi-110012, India
}

*Corresponding author

\section{A B S T R A C T}

Keywords

Tomato, Hybrids,

Parental lines,

Genetic variation,

Stomata

Article Info

Accepted:

10 December 2018

Available Online:

10 January 2019
The present study is an attempt to differentiate tomato hybrids from its parental lines using stomatal characters like stomatal density, length and width of guard cells on both the adaxial and abaxial surfaces and to assess the genetic variation for these traits. Significant differences were found for stomata characters like stomata density, length, width and area of stomata on both adaxial and abaxial surfaces of cotyledonary leaf. Hybrids recorded significantly higher stomata densities than one or both their parental lines. The differences were more conspicuous on the abaxial surface than adaxial surface. The present study was an attempt to differentiate hybrid from its parental lines and the hybrid had clear distinction from one of its parental line

\section{Introduction}

Tomato (Solanum lycopersicum $\mathrm{L}$ ), $2 \mathrm{x}=24$, a member of Solanaceae, originated from the Andean region now consisting parts of Chile, Bolivia, Ecuador, Columbia and Peru (Sims, 1980). With the revised phylogenetic classification of the family Solanaceae, the genus Lycopersicum was re-integrated into genus Solanum, attaining its new nomenclature. Solanum section Lycopersicum encompasses the cultivated tomato ( $S$. lycopersicum) along with its wild relatives
(Peralta et al., 2006). Contrast to the rich reservoir in wild species, cultivated tomatoes are genetically poor with $<5 \%$ of genetic variation of their wild relatives (Miller and Tanksley, 1990). Besides that tomato being a predominantly self-pollinated crop tends to lose its genetic variability even without selection. One of the avenues given for improving the productivity is developing and adopting hybrid tomato cultivation. Hybrids combine good characters from both the parental lines and have an advantage over their parental lines or any other open 
pollinated varieties. For conducting genetic purity testing, a cultivar has to be defined with its distinguishing characters. Further, India being a signatory to WTO agreement on TRIPS, passed the Protection of Plant Varieties and Farmers Right Act (2001) for protecting new varieties. The identity of a cultivar has to be established using morphological, physiological, biochemical and molecular characters. Until date, morphological characters both qualitative and quantitative form the bulk of varietal characterization and they have been universally accepted, as undisputed characters when used in sequential fashion thus making them convenient for distinguishing the different varieties. The narrow genetic base in the process of evolving new tomato genotypes makes it difficult to distinguish genotypes easily. Also, the time taken to observe the characters over a growing season has generated interest in searching and utility of other morphological markers which are precise in varietal identification. The present study is aimed to know the genetic variation of different stomatal and root characters in hybrids and their parental lines of tomato.

\section{Materials and Methods}

A total of four tomato hybrids and their parental lines (Table 1) developed and released by Division of Vegetable Science, ICAR-Indian Agricultural Research Institute, New Delhi were used in the present study.

For studying the stomatal characters experiment was conducted on seedlings raised in plug-trays, in the divisional walk-in-room germinator maintaining $25^{\circ} \mathrm{C}$. Seedlings from all genotypes were raised in plug trays with single seedling in each plug for 15 days. Fully expanded cotyledonary leaves of seedlings, 15-18 days old, were selected for stomata studies (stage coincided with the emergence of apical primordial leaf). Epidermal peels of ten seedlings were obtained from both abaxial and adaxial surfaces. For deriving the epidermal peels, the cotyledonary leaf was placed on a flat surface and covered with a clear cellophane tape. Gentle pressure was applied all along the tissue and the tape pulled off from the leaf by holding the leaf with other hand. The epidermal peel still adhered to the tape is mounted as such on to a slide. The specimen was observed under 10X magnification of Leica DM750 stereo microscope. Observations on stomata density (number per $\left.\mathrm{mm}^{2}\right)$, length $(\mu \mathrm{m})$, width $(\mu \mathrm{m})$ and area $\left(\mu \mathrm{m}^{2}\right)$ were recorded.

Pair wise comparisons (between the parental lines, hybrid with female parental line and hybrid with male parental line) were made following ' $t$ '-test proposed by Cochran and Cox approximation (Chandel, 1993) for all the traits.

\section{Results and Discussion}

Significant differences were found for stomata characters like stomata density, length, width and area of stomata on both adaxial and abaxial surfaces of cotyledonary leaf (Table 2 and 3).

Stomata density was higher on abaxial surface than adaxial surface of cotyledonary leaf for all genotypes under study. PH-1 (15.6), PH-2 (16.7) and $\mathrm{PH}-4$ (16.1) were significantly different from their respective parental lines. PH-2 and PH-4 recorded mid-parent values (intermediate values between the parental lines), whereas PH-1 was superior to the better parental line for stomata density. Hybrid $\mathrm{PH}-8$ (16.1) recorded on par stomata density with its female parental line (16.9), and recorded significantly higher values than its male parental line (13.0).

Stomata density on adaxial surface was found to be significantly different for the hybrids and 
their parental lines. For PH-1 (9.1), PH-2 (10.1) and PH-4 (9.3), the values were on par with their female parental line $(9.0,10.1$ and 10.1 , respectively) and significantly different from their corresponding male parental lines (7.7, 10.8 and 7.7, respectively). PH-8 (10.1) had stomata density on par with its male parental line (10.2), and recorded significantly lower stomata density than its female parental line (11.4).

Length of stomata on abaxial surface was on par for two hybrids $\mathrm{PH}-1(31.0 \mu \mathrm{m})$ and $\mathrm{PH}-2$ $(30.7 \mu \mathrm{m})$ than their parental lines. PH-4 (30.6 $\mu \mathrm{m})$ had significantly smaller stomata (guard cells) length than its male parental line (32.4 $\mu \mathrm{m})$. PH-8 (29.6 $\mu \mathrm{m})$ had significantly longer stomatal guard cells than both of its parental lines. Length of stomata guard cells on adaxial surface was observed to be on par with their respective parental lines in $\mathrm{PH}-2(30.7 \mu \mathrm{m})$ and PH-4 (30.4 $\mu \mathrm{m})$. For PH-1 $(30.4 \mu \mathrm{m})$, the difference was significantly greater than its female parental line $(28.8 \mu \mathrm{m})$, and on par with its male parental line $(30.5 \mu \mathrm{m})$. PH-8 $(29.6 \mu \mathrm{m})$ recorded significantly higher stomata length against its male parental line $(28.1 \mu \mathrm{m})$, and was on par with its female parental line $(28.9 \mu \mathrm{m})$ (Table 2 and 3$)$.

Stomata width on abaxial surface was observed to be on par with their parental lines for hybrids PH-1 $(21.0 \mu \mathrm{m})$ and PH-2 (20.6 $\mu \mathrm{m})$. PH-4 $(21.5 \mu \mathrm{m})$ and $\mathrm{PH}-8(20.4 \mu \mathrm{m})$ recorded stomata width, which was on par with their male parental line $(20.2 \mu \mathrm{m}$ and $19.4 \mu \mathrm{m}$, respectively). Width of adaxial stomata was found to be statistically different from their respective female parental lines for PH-2 (19.7 $\mu \mathrm{m})$ and PH-8 $(20.2 \mu \mathrm{m})$, and on par with their male parental lines $(19.8 \mu \mathrm{m}$ and $19.9 \mu \mathrm{m}$, respectively). Stomata width was observed to be on par with both the parental lines in PH-4 $(20.0 \mu \mathrm{m})$, and significantly different from both the parental lines in PH-1 (19.7 $\mu \mathrm{m})$ (Table 2 and 3).
Size of stomata on abaxial surface was statistically higher than both of its parental lines in $\mathrm{PH}-8\left(606.1 \mu \mathrm{m}^{2}\right)$. In $\mathrm{PH}-1$ (649.6 $\left.\mu \mathrm{m}^{2}\right)$, PH-2 $\left(633.9 \mu \mathrm{m}^{2}\right)$ and $\mathrm{PH}-4$ (657.9 $\mu \mathrm{m}^{2}$ ), the values observed were on par with both parental lines. PH-1 $\left(599.2 \mu \mathrm{m}^{2}\right), \mathrm{PH}-2$ $\left(608.6 \mu \mathrm{m}^{2}\right)$ and PH-4 $\left(609.1 \mu \mathrm{m}^{2}\right)$ could not be distinguished from both of their parental lines with adaxial surface stomata size whereas the values were found to be statistically higher than those to both of parental lines in PH-8 $\left(599.5 \mu \mathrm{m}^{2}\right)$.

Ratio of stomata density on adaxial to abaxial surface was observed to be statistically different than those to both of parental lines in PH-2 (0.61). In PH-1 (0.55), the observations recorded on ratio of stomata showed that the hybrid had on par ratio with the male parental line (0.57), and significantly lower stomata density ratio against its female parental line (0.60). PH-8 recorded on par ratio for stomata density (0.63) in adaxial to abaxial surface with its female parental line, and significantly lower ratio with its male parental line $(0.80)$. $\mathrm{PH}-4$ recorded on par stomata density ratio (0.58) with both of its parental lines.

Stomata are small pores surrounded by guard cells (Bosoet al., 2010). They are primarily engaged in gas exchange and regulation of water losses. The distribution of stomata varies from surface to surface of leaves, position of leaves on the shoot and external weather conditions. So, the results tend to vary if genotypes under question are not raised under similar climatic conditions (Campo et al., 2004). Therefore, to study the differences in stomata characters, seedlings were raised in walk-in-room germinator in the division of Seed Science and Technology, ICAR-IARI, New Delhi and samples were taken from 15 to 18-day-old cotyledonary leaf to minimize the effect of environment on stomata development. Significant differences were observed for stomata density, length, width 
and area on both surfaces of cotyledonary leaf among the genotypes studied. Hybrids recorded significantly higher stomata densities than one or both their parental lines. The differences were more conspicuous on the abaxial surface than adaxial surface. No clear relationship was seen regarding the number and size of stomata. For instance, hybrids in general having higher stomata density had on par stomata measurements with parental lines having lower stomata density (eg: $\mathrm{PH}-1)$.

Table.1 Tomato hybrids and their parental lines used in the study

\begin{tabular}{|c|c|c|}
\hline Hybrid & Female & Male \\
\hline PH-1 & Female-1 & Male-1 \\
\hline PH-2 & Female-2 & Male-2 \\
\hline PH-4 & Female-2 & Male-1 \\
\hline PH-8 & Female-3 & Male-3 \\
\hline
\end{tabular}

Table.2 Stomata* characters of cotyledonary leaves in tomato hybrids and their parental lines

\begin{tabular}{|l|c|c|c|c|}
\hline \multirow{2}{*}{ Genotype } & \multicolumn{4}{|c|}{ Stomata } \\
\cline { 2 - 5 } & Density & Length $(\boldsymbol{\mu m})$ & Width $(\boldsymbol{\mu m})$ & Area $\left(\boldsymbol{\mu m}^{2}\right)$ \\
\hline Female-1 & $15.1 \pm 0.2 \mathrm{a}$ & $31.4 \pm 0.5 \mathrm{a}$ & $21.1 \pm 0.4 \mathrm{a}$ & $660.0 \pm 15.8 \mathrm{a}$ \\
\hline PH-1 & $15.6 \pm 0.1 \mathrm{c}$ & $31.0 \pm 0.6 \mathrm{a}$ & $21.0 \pm 0.4 \mathrm{a}$ & $649.6 \pm 19.1 \mathrm{a}$ \\
\hline Male-1 & $13.6 \pm 0.4 \mathrm{~b}$ & $32.4 \pm 0.6 \mathrm{a}$ & $20.2 \pm 0.5 \mathrm{a}$ & $678.8 \pm 23.4 \mathrm{a}$ \\
\hline
\end{tabular}

\begin{tabular}{|l|c|c|c|c|}
\hline \multirow{2}{*}{ Genotype } & \multicolumn{4}{|c|}{ Stomata } \\
\cline { 2 - 5 } & Density & Length $(\boldsymbol{\mu m})$ & Width $(\boldsymbol{\mu m})$ & Area $\left(\boldsymbol{\mu m}^{2}\right)$ \\
\hline Female-2 & $19.0 \pm 0.5 \mathrm{c}$ & $30.7 \pm 0.6 \mathrm{a}$ & $19.7 \pm 0.4 \mathrm{a}$ & $603.2 \pm 22.2 \mathrm{a}$ \\
\hline PH-2 & $16.7 \pm 0.1 \mathrm{~b}$ & $30.7 \pm 0.8 \mathrm{a}$ & $20.6 \pm 0.5 \mathrm{a}$ & $633.9 \pm 23.7 \mathrm{a}$ \\
\hline Male-2 & $14.9 \pm 0.3 \mathrm{a}$ & $29.8 \pm 0.6 \mathrm{a}$ & $19.4 \pm 0.4 \mathrm{a}$ & $581.2 \pm 21.3 \mathrm{a}$ \\
\hline
\end{tabular}

\begin{tabular}{|l|c|c|c|c|}
\hline \multirow{2}{*}{ Genotype } & \multicolumn{4}{|c|}{ Stomata } \\
& Density & Length $(\boldsymbol{\mu m})$ & Width $(\boldsymbol{\mu m})$ & Area $\left(\boldsymbol{\mu m}^{2}\right)$ \\
\hline Female-2 & $19.0 \pm 0.5 \mathrm{c}$ & $30.7 \pm 0.6 \mathrm{a}$ & $19.7 \pm 0.4 \mathrm{a}$ & $603.2 \pm 22.2 \mathrm{a}$ \\
\hline PH-4 & $16.1 \pm 0.2 \mathrm{~b}$ & $30.6 \pm 0.6 \mathrm{a}$ & $21.5 \pm 0.8 \mathrm{~b}$ & $657.9 \pm 22.2 \mathrm{a}$ \\
\hline Male-1 & $13.6 \pm 0.4 \mathrm{a}$ & $32.4 \pm 0.6 \mathrm{~b}$ & $20.2 \pm 0.5 \mathrm{ab}$ & $678.8 \pm 23.4 \mathrm{a}$ \\
\hline
\end{tabular}

\begin{tabular}{|l|c|c|c|c|}
\hline \multirow{2}{*}{ Genotype } & \multicolumn{4}{|c|}{ Stomata } \\
\cline { 2 - 5 } & Density & Length $(\boldsymbol{\mu m})$ & Width $(\boldsymbol{\mu m})$ & Area $\left(\boldsymbol{\mu m}^{2}\right)$ \\
\hline Female-3 & $16.9 \pm 0.6 \mathrm{a}$ & $27.9 \pm 0.3 \mathrm{~b}$ & $19.5 \pm 0.3 \mathrm{a}$ & $544.7 \pm 11.0 \mathrm{a}$ \\
\hline PH-8 & $16.1 \pm 0.2 \mathrm{a}$ & $29.6 \pm 0.3 \mathrm{a}$ & $20.4 \pm 0.2 \mathrm{~b}$ & $606.1 \pm 8.1 \mathrm{~b}$ \\
\hline Male-3 & $13.0 \pm 0.4 \mathrm{~b}$ & $27.9 \pm 0.4 \mathrm{~b}$ & $19.4 \pm 0.5 \mathrm{ab}$ & $543.3 \pm 20.1 \mathrm{a}$ \\
\hline
\end{tabular}

*Stomata were studied from lower surface (LS) or abaxial surface, where, values are mean values \pm standard error, Values with same letters are statistically on par; and with different letters are significantly different 
Table.3 Stomata* characters of cotyledonary leaves in tomato hybrids and their parental lines

\begin{tabular}{|l|c|c|c|c|c|}
\hline \multirow{2}{*}{ Genotype } & \multicolumn{5}{|c|}{ Stomata } \\
\cline { 2 - 6 } & Density & Length $(\boldsymbol{\mu m})$ & Width $(\boldsymbol{\mu m})$ & Area $\left(\boldsymbol{\mu m}^{2}\right)$ & Density ratio (US/LS) \\
\hline Female-2 & $10.1 \pm 0.3 \mathrm{a}$ & $30.6 \pm 0.3 \mathrm{a}$ & $20.6 \pm 0.1 \mathrm{a}$ & $631.0 \pm 7.2 \mathrm{a}$ & $0.50 \pm 0.02 \mathrm{a}$ \\
\hline PH-2 & $10.1 \pm 0.2 \mathrm{a}$ & $30.7 \pm 0.3 \mathrm{a}$ & $19.7 \pm 0.3 \mathrm{~b}$ & $608.6 \pm 11.0 \mathrm{a}$ & $0.60 \pm 0.01 \mathrm{~b}$ \\
\hline Male-2 & $10.8 \pm 0.2 \mathrm{ab}$ & $30.2 \pm 0.3 \mathrm{a}$ & $19.8 \pm 0.4 \mathrm{ab}$ & $597.9 \pm 17.6 \mathrm{a}$ & $0.70 \pm 0.02 \mathrm{c}$ \\
\hline
\end{tabular}

\begin{tabular}{|l|c|c|c|c|c|}
\hline \multirow{2}{*}{ Genotype } & \multicolumn{5}{|c|}{ Stomata } \\
\cline { 2 - 6 } & Density & Length $(\boldsymbol{\mu m})$ & Width $(\boldsymbol{\mu m})$ & Area $\left(\boldsymbol{\mu m}^{2}\right)$ & Density ratio (US/LS) \\
\hline Female-2 & $10.1 \pm 0.3 \mathrm{a}$ & $30.6 \pm 0.3 \mathrm{a}$ & $20.6 \pm 0.1 \mathrm{a}$ & $631.0 \pm 7.2 \mathrm{a}$ & $0.50 \pm 0.02 \mathrm{a}$ \\
\hline PH-4 & $9.3 \pm 0.3 \mathrm{a}$ & $30.4 \pm 0.3 \mathrm{a}$ & $20.0 \pm 0.5 \mathrm{a}$ & $609.1 \pm 16.7 \mathrm{a}$ & $0.57 \pm 0.02 \mathrm{a}$ \\
\hline Male-1 & $7.7 \pm 0.4 \mathrm{~b}$ & $30.5 \pm 0.8 \mathrm{a}$ & $20.5 \pm 0.2 \mathrm{a}$ & $626.0 \pm 19.6 \mathrm{a}$ & $0.60 \pm 0.03 \mathrm{a}$ \\
\hline \multirow{5}{*}{ Genotype } & \multicolumn{5}{|c|}{ Stomata } \\
\cline { 2 - 7 } & Density & Length $(\boldsymbol{\mu m})$ & Width $(\boldsymbol{\mu m})$ & Area $\left(\boldsymbol{\mu m}^{2}\right)$ & Density ratio (US/LS) \\
\hline Female-3 & $11.4 \pm 0.4 \mathrm{a}$ & $28.9 \pm 0.4 \mathrm{a}$ & $19.2 \pm 0.3 \mathrm{a}$ & $555.3 \pm 11.8 \mathrm{a}$ & $0.70 \pm 0.03 \mathrm{a}$ \\
\hline PH-8 & $10.1 \pm 0.1 \mathrm{~b}$ & $29.6 \pm 0.3 \mathrm{a}$ & $20.2 \pm 0.2 \mathrm{~b}$ & $599.5 \pm 9.2 \mathrm{~b}$ & $0.62 \pm 0.01 \mathrm{a}$ \\
\hline Male-3 & $10.2 \pm 0.3 \mathrm{~b}$ & $28.1 \pm 0.5 \mathrm{ab}$ & $19.9 \pm 0.3 \mathrm{ab}$ & $559.5 \pm 14.2 \mathrm{ac}$ & $0.80 \pm 0.02 \mathrm{~b}$ \\
\hline
\end{tabular}

* Stomata were studied from upper surface (US) /adaxial surface, where, values are mean values \pm standard error, Values with same letters are statistically on par; and with different letters are significantly different

Wilkinson (1995) reported the stronger variability for stomata density rather than stomata index between varieties of a species. The genetic control of stomata distribution was reported by Meiselet al (2011), wherein they proposed specialized vision system which allows to perceive light signals initiating biochemical events. This in turn triggers downstream response. Sugano et al (2010) also reported an intercellular signal factor called stomagen produced by mesophyll cells in Arabidopsis. It interacts with epidermal cell factors to influence stomata density.

Further, no clear relationship could be seen between leaf size and stomata density or stomata size. The present study was an attempt to differentiate hybrid from its parental lines provides interesting results as the hybrid had clear distinction from one of its parental line (mostly males in the present study). The utility of this character in establishing hybridity as against its conventional reference for drought screening is reported (Medrano et al., 2002; Venora and Calcagno, 1991).

\section{Acknowledgement}

Dr. SR Bhat, Principal Scientist(Molecular Biology), NRCPB for providing the lab facilities and Dr. DK Yadava, Head, Division of Seed Science and Technology, ICARIndian Agricultural Research institute, New Delhi is acknowledged for release of funds.

\section{References}

Boso, S., A.V. VillaVerde, J. Santiago, P. Gago, D.M. Berger, M. Düggelin, H.H. Kassemeyer and M.C. Martínez. 2010. Macro- and microscopic leaf characteristics of six grapevine genotypes (Vitisspp.) with different susceptibilities to grapevine downy 
mildew. Vitis. 49, 43-50.

Campo, G.M., P. Baeza, C. Ruiz and J.R. Lissarrague. 2004. Water-stress induced physiological changes in leaves of four container-grown grapevine cultivars (Vitis vinifera L.). Vitis.43, 99-105.

Chandel S.R.S., 1993. A Handbook of Agricultural Statistics Achal Prakash Mandiv, Pandunagar, Kanpur., pp. A193- A194.

Medrano, H., J.M. Escalona, J. Bota, J. Gulías and J. Flexas. 2002. Regulation of photosynthesis of $\mathrm{C} 3$ plants in response to progressive drought: stomatal conductance as a reference parameter. Ann. Bot. 89, 895-905.

Meisel, L., D. UrBina and M. Pinto. 2011.Fotorreceptores y respuestas de plantas a señaleslumínicas (online). In: F. SQueo, 1. CardeMil, (Eds): Fisiología vegetal. Ediciones Universidad de $\mathrm{La}$ Serena, La Serena. Chile. 18, 1-10.
Miller, J.C. and S.D. Tanksley. 1990. RFLP analysis of phylogenetic relationships and genetic variation in the genus Lycopersicon. Theor. Appl. Genet. 80, 437-448.

Peralta, I.E., S. Knapp and D.M. Spooner. 2006. Nomenclature for wild and cultivated tomatoes Tomato Genetics Cooperative Report. 56, 6- 12.

Sims, W.L., 1980. History of tomato production for industry around the world. ActaHortic. 100, 25-26.

Sugano, S. S., T. Shimada, Y. Mai, K. Okawa, A. Tamai, M. Mori and H. Shimura. 2010. Stomagen positively regulates stomatal density in Arabidopsis. Nature. 463, 241-244.

Venora, G., and F. Calcagno. 1991. Study of stomatal parameters for selection of drought resistant varieties in Triticum durum DESF. Euphytica. 57, 275-283.

\section{How to cite this article:}

Chennem Kiran Kumar Reddy, Sudheer Kumar Jain, M.B. Arun Kumar, S. Gopala Krishnan, Awani Kumar Singh and Zakir Hussain. 2019. Genetic Variation of Stomatal Traits in Four Tomato Hybrids and their Parental Lines. Int.J.Curr.Microbiol.App.Sci. 8(01): 1190-1195. doi: https://doi.org/10.20546/ijcmas.2019.801.125 